DOI https://doi.org/10.30525/978-9934-26-073-5-2-73

\title{
ФУНКЦІЮВАННЯ КОМПЕТЕНТНІСНОГО ПІДХОДУ \\ НА ЗАНЯТТЯХ 3 ІНОЗЕМНОЇ МОВИ ЗА ПРОФЕСІЙНИМ СПРЯМУВАННЯМ
}

\begin{abstract}
Сіліщенко О. П.
викладач

Відокремленого структурного підрозділу «Херсонський політехнічний фаховий коледж Державного університету «Одеська політехніка»
\end{abstract}

Лосєва Ю. В.

викладач

Відокремленого структурного підрозділу «Херсонський політехнічний фаховий коледж Державного університету «Одеська політехніка»

м. Херсон, Украӥна

Зважаючи на сьогоденні зміни у потребах суспільства, пріоритетним напрямком у вивченні іноземних мов стало опанування ними, як засобом спілкування. Головне завдання вищого навчального закладу - підготовка спеціалістів здатних нестандартно, гнучко та своєчасно реагувати на зміни, які відбуваються у світі. У рамках сучасних викликів іншомовна комунікація $є$ необхідним елементом взаємодії людей, груп i навіть держав. Тому слід підготувати спеціалістів, здатних до активного співробітництва, які відрізняються мобільністю, динамізмом та конструктивністю.

3 огляду на вищесказане, саме компетентнісний підхід у навчанні означає зміщення акценту з накопичування знань, умінь i навичок на формування та розвиток у студентів ключових і предметних компетентностей та вміння їх практично застосовувати. Компетентнісний підхід знайшов своє відображення у визначенні мети навчання іноземної мови: формування у здобувачів освіти комунікативної компетентності - умінь i навичок здійснювати спілкування в усній і письмовій формах у межах сфер i тематики, визначених навчальною програмою для кожного профілю, дотримуючись традицій і норм, прийнятих у країні, мова якої вивчається [3]. Особливо актуальним наразі $є$ компетентнісний підхід до вивчення іноземних мов у сфері розвитку культури професійного мовлення та комунікативної компетенції [1, с. 118].

Необхідно зауважити, що компетентнісний підхід в навчанні не $\epsilon$ абсолютно новим, а його концепція з'явилася в 1960 році в США. Вона 
визначала те, що студент буде вміти виконувати в тій чи іншій області по завершенню вивчення модуля, курсу або освітньої програми підготовки фахівця. Цей підхід пропагував визначити цілі з точки зору виміряного опису знань, умінь і дій, якими здобувачі освіти повинні оволодіти в кінці певного курсу навчання [5].

Одним 3 напрямків роботи циклової комісії іноземної мови в Херсонському політехнічному фаховому коледжі $\epsilon$ формування комунікативної компетентності студентів, використовуючи елементи комунікативної методики навчання, особливість якої полягає в тому, що навчання орієнтоване скоріше не на те, що випускники будуть знати, а на те, що вони будуть вміти робити. Викладач повинен приділяти особливу увагу кінцевим результатам процесу навчання, а саме навичкам, достатнім для того, щоб виконувати певні завдання у професійній діяльності.

Головним аспектом цієї системи $\epsilon$ розробка точних, чітких наборів результатів, навколо яких організовані всі інші компоненти, a також i визначення умов i можливостей, завдяки яким студенти змогли б досягти цих конкретних результатів. Для цього слід використовувати таксономію американського вченого Блума [7].

Мета таксономії Блума - зосереджуватися на всіх рівнях, надаючи можливість формувати повний обсяг професійних навичок, для засвоєння компететності. Вони класифікуються на такі рівні: «я знаю, розумію, можу використовувати, проаналізувати, оцінити, створити». Всередині кожного окремого рівня для переходу на більш високий необхідний досвід попередніх. Кожен вищевказаний рівень має список дієслів для формування результатів навчання. Наприклад, рівні «розуміння і застосування» включають такі дієслова: ідентифікувати, застосовувати, відтворити, вирішити, показати і т.д.

Викладачі ЦК іноземної мови застосовують цю систему при формуванні результатів навчання після завершення одного заняття, розділу або курсу. Наприклад, після завершення вивчення теми «Компоненти комп`ютера» студент повинен володіти такими професійними навичками:

1) ідентифікувати складові компютера, функції їх призначення (англійською мовою);

2) виправити несправності,( вживаючи набір мовленнєвих зразків за темою англійською мовою);

3) розпізнавати помилки програми і т.д.

Комунікативна методика навчання як елемент реалізації компетентнісного підходу кардинально відрізняється від традиційного [6, с. 83]. Так, якщо в традиційній методиці потрібно ставити практичні, 
виховні, освітні, розвиваючі цілі, і вони звучать приблизно так: «розвивати навички говоріння, читання, використовувати ту чи іншу граматичну структуру», то згідно з компетентнісним підходом це методично неграмотно, так як ці навички та вміння неможливо виміряти. Адже розвивати ті чи інші навички та вміння можна протягом усього життя, а ми повинні протягом одного заняття, розділу, семестра i відповідно за весь період навчання в коледжі навчити студентів застосовувати знання, уміння і навички для вирішення професійних завдань.

Одним 3 основних завдань викладача, використовуючи компетентнісне навчання, є розробляти навчальні заняття відповідно до професійного навика, який студент повинен засвоїти [4].

Такі професійні навички визначені у відповідних освітніх програмах. Здобувач освіти повинен усвідомити, що саме йому необхідно знати, розуміти і з якою метою він буде користуватися певним навиком. У зв'язку з цим, дуже важливо, щоб кожен професійний навик засвоювався окремо. Це є обов'язковою умовою компетентнісного навчання, тобто поступальний рух від одного засвоєного професійного навика до іншого 3 метою досягнення більш високої кінцевої навчальної мети.

Наприклад, до способів прояву компетентності в говорінні можна віднести наступні вміння: адекватно вести себе в типових професійних і побутових ситуаціях виробничого характеру: на СТО, електромонтажній дільниці, в бухгалтерському відділі; спілкуватися з приводу змісту правил та інструкцій з безпеки; швидко реагувати на зміни ходу бесіди, гнучко використовуючи загальновживані фрази і т. д. Для того, щоб формування компетентності мало поступальний характер, розподіл змісту всього навчального матеріалу погоджується 3 його поступовим оволодінням.

На першому курсі студенти вивчають матеріал, пов'язаний 3 навичками використання іноземної мови в повсякденному житті. На другому курсі студенти засвоюють навички базової професійної англійської мови, яка $€$ загальною для всіх політехнічних спеціальностей. Третій курс присвячений виключно навичкам, які необхідні для програмістів, електромеханіків, механіків, турагентів, економістів і т.д.

Навчальні завдання, які використовуються при компетентнісному підході, можна описати як завдання, які систематично розробляються для формування певного професійного досвіду з реального життя, а особливо для ситуацій, пов'язаних з майбутньою професією.

Разом 3 цим, важливим $є$ створення практикумів, завдань до виконання самостійних робіт, методичних вказівок до виконання самостійних робіт, навчальних посібників (навчального матеріалу), які 
відповідають необхідним навичкам 3 професійними завданнями, які учасники освітнього процесу будуть вирішувати під час роботи за фахом.

Так, у структурі практичного заняття з англійської мови заключний етап заняття називається «Застосування», в процесі якого викладач створює реальну ситуацію, в якій студент повинен застосувати той чи інший навик. Наприклад, вивчаючи текст за фахом «Маршрутизатор (роутер)» на заняттях з іноземної мови за професійним спрямуванням спеціальності «Комп ютерна інженерія» викладач створює реальну ситуацію: «Відбувся збій у роботі роутера. Ваші дії? Зв`яжіться 3 адміністратором мережі, виконайте інструкції щодо відновлення зв язку (чи бачите ви мене в мережі? чи отримуєте Інтернет? перевірте мережеву карту та якість роз єму) [2, с. 73].

Отже, ми можемо висновувати, що під час реалізації компетентнісного навчання необхідно зосереджуватися на результатах, які відповідають вимогам роботодавця; навчати здобувачів освіти застосовувати знання, уміння і навички для вирішення реальних завдань, які виконуються на робочому місці, замість концентрації на теоретичних знаннях за рахунок здатності виконувати роботу; формувати чіткі вимірювані результати навчання, тобто встановлювати конкретні практичні цілі в навчальних програмах; проводити оцінювання на основі засвоєння професійних навичок; брати до уваги знання, вміння, дії, необхідні для фактичного досягнення тієї чи іншої професійної мети.

\section{Література:}

1. Вишневський О.І. Методика навчання іноземних мов: Навч. посіб. 2-ге вид.,перероб. і доп. К: Знання, 2011. 206 с.

2. Вочканова Т.В. Англійська у світі інформаційних технологій. Іноземні мови в навчальних закладах. 2010. №5. 87 с.

3. Державний стандарт базової і повної загальної середньої освіти. Постанова Кабінету Міністрів України від 23 листопада 2011 р. № 1392. URL: https://zakon.rada.gov.ua/laws/show/1392-2011-\%D0\%BF.

4. Методика навчання іноземних мов у середніх навчальних закладах: Підручник. кол. авторів під керівн. С.Ю. Ніколаєвої. К: Ленвіт, 1999. $320 \mathrm{c}$.

5. Пометун О. Запровадження компетентнісного підходу перспективний напрям розвитку сучасної освіти. URL: http:// visnyk.iatp.org.ua.

6. Родніна I. В. Компетентнісно орієнтований підхід до навчання. Харків: Основа, 2006. 94 с.

7. Таксономія Блума. URL: https://uk.wikipedia.org/wiki/. 